\title{
Cooperative Learning Method in the Practice of English Reading and Speaking
}

\author{
Jing Meng \\ College of Foreign Languages, Qingdao University of Science and Technology, Qingdao 266061, China \\ Email:laserain@163.com
}

\begin{abstract}
As is known to all, fostering the students' ability to use the language in real situations mainly depends on the teaching and learning method. In traditional language classrooms, students are taught chiefly about language and its rules. They learn facts about language rather than how to use it communicatively to express ideas and read real language. In order to reform traditional teaching approaches, the author tries to combine cooperative learning with the teaching of English reading and speaking for the purpose of confirming that cooperative learning is more effective in teaching English in Colleges.
\end{abstract}

Index Terms - cooperative learning, language teaching, reading, speaking

\section{INTRODUCTION}

Foreign language teaching has developed and gained diverse achievements in recent years. Various kinds of approaches, such as grammar-translation, audio-lingual, natural approach etc, emerged and dominated the field of FLT in different periods. China, influenced by the main trend, also underwent several stages during which different facets of language learning were emphasized and had gained rapid progress. Nowadays, English has been an international language and is used to a greater and greater degree. However, not all the learners who involve in English-learning could end up with fruitful rewards. One serious problem is quite astonishing: most learners, though they have mastered a great number of vocabularies and could engrave a great deal of grammatical rules in their minds, can hardly speak out a complete sentence, or write down a correct one. In order to deal with this situation, this paper intends to find out an effective way to help college students enhance their reading and speaking ability.

In China, most college English classes are made up of at least 40-50 students. In each class, one third of the students are less efficient students. The students are generally reserved and reluctant to use English. Many of them also become embarrassed if they make a mistake when speaking in front of other students. So teachers must find some ways to boost the students' self-confidence, to motivate and encourage them and thereby improve their fluency. So teachers need to be able to manage their interaction with the class in a way that allows all students equal opportunities to participate; learners also need to learn how they are expected to interact in the classroom.

Group work and pair work have become increasingly popular in language teaching since they are seen to have many advantages. Group work is a cooperative activity: four students, perhaps with a topic, are doing a role-play or solving a problem. In groups, students tend to participate more equally, and they are also more able to experiment and use the language than they are in a whole-class arrangement.

Pair work has many of the same advantages. The moment students get into pairs and start working on a problem or talking about something, many more of them will be doing the activity than if the teacher was working with the whole class, where only one student talks at a time.

Both pair work and group work give the students chances for greater independence. Because they are working together without the teacher controlling every move, they take some of their own learning decisions, they decide what language to use to complete a certain task, and they can work without the pressure of the whole class listening to what they are doing.

\section{ANALYSIS OF THE TRADITIONAL TEACHING METHOD}

It has been observed that it is difficult for the Chinese students to communicate with the native speakers, although they began to learn English from Grade 4 in primary schools. The occurrence of the phenomenon is closely related to the traditional teaching methods that have some weakness in themselves.

As we have seen, the traditional mode of classroom organization was a teacher-centered one, with learners sitting in rows facing the teacher. The students spent most of their time repeating and manipulating models provided by the teacher, the textbook, and the tape and developed skills in choral speaking and repeating. In this way, the students learned how to memorize individual words and grammatical patterns, and to practice them in contrived contexts; the underlying strategies behind the classroom tasks were rarely made explicit. As a result, some of the students in such classrooms could read texts correctly with beautiful intonation, could memorize a lot of words and expressions, but they rarely learned how to make use of this stored knowledge in an organized or creative way. That is to say, they do not 
learn how to express their own ideas and to share these ideas by communicating with other people. Therefore, developing the students' ability to use the language in real situations is the main task for all the teachers.

A. The Current Conditions of College English Classes

\section{B. Students Are at Different Levels}

One of the biggest problems teachers face is to teach a class with the students of different levels. Some are efficient learners of English, some are less efficient learners, and some are problem learner, which makes it difficult for the teachers in class. Some students, especially the less efficient ones, have no interest in English, so they don't like to participate in the activities. If the teachers pay more attention to those students, that is to say, teach at a slow speed, the efficient students will feel bored. If not, the less efficient students will feel they are neglected.

\section{The Class Is Very Big}

In China, most college English classes consist of at least 40 students, some even come to 80 . As we can see, in big classes, it is difficult for the teacher to make contact with all the students in class and it is difficult for the students to ask for and receive individual attention. It may seem impossible to organize dynamic and creative teaching and learning sessions. Most of the students don't have enough chances to practice English.

\section{The Teacher's Action Zone}

According to Richards \& Lockhart (1996), in class, it is true that despite a teacher's best intentions, teachers sometimes interact with some students in the class more frequently than others. Although teachers generally try to treat students fairly and give every student in the class an equal opportunity to participate in the lesson, it is often hard to avoid interacting with some students more than others. This creates what is referred to as the teacher's action zone.

Students located within the teacher's action zone are likely to participate more actively in a lesson than students who fall outside that action zone. In many classrooms, this zone includes the middle front row seats. If a teacher is teaching from the front of the class, students seated there are more likely to have the opportunity to participate actively because of their proximity to the teacher.

Although a teacher may feel that all the students in the class have an equal opportunity to participate in the lesson, it is not always so. It also seems that the teacher overlooked the students sitting in the right and left rows, and had an action zone located in the center of the room. If active participation is important in learning, then those students not within the teacher's action zone are at a disadvantage.

In order to improve the existing situation in College English teaching, this paper introduces cooperative learning into the classroom.

\section{DEFINITIONS OF COOPERATIVE LEARNING}

Many scholars proposed their own but actually rather similar definitions. According to Olsen \& Kagan (1992), cooperative learning is defined as "group learning activities organized so that learning is dependent on the socially structured exchange of information between learners in groups and in which each learner is held accountable for his or her own learning and is motivated to increase the learning of others". Paul J. Vermette (1998) defined cooperative learning in this way: "A cooperative classroom team is a relatively permanent, heterogeneously mixed, small group of students who have been assembled to complete an activity, produce a series of projects or products and/or who have been asked to individually master a body of knowledge. The spirit within the team has to be one of positive interdependence, that is, a feeling that success for any one is tied directly to the success of others". To put it more concretely, cooperative learning approach defines the class as heterogeneous groups, the class is organized in groups of four or six students in order to fulfill a learning task cooperatively. The learning task is based on interaction and reciprocal interdependence among the members of group and requires mutual help. In this educational approach, students and teachers are in a state of dynamic cooperation and together build up an intimate learning and social atmosphere in the classroom. The textbooks and the teacher are no longer the only source of information, but are replaced by a variety of other people.

\section{The SignifiCANCE OF COOPERATIVE LEARning IN COLLEGE ENGLish CLASS}

Students need practice in producing comprehensive output (Swain 1985) using all the language resources they have already acquired. Getting feedback from the teacher and from other students in the class enables learners to test hypotheses and refine their developing knowledge of the language system. When a group of students do this while talking together it is called negotiation of meaning and its aim is to make output more comprehensible. There is a principle underlying current ELT practice that interaction pushes learners to produce more accurate and appropriate language, which itself provides input for other students. This is one reason why group work has become popular in contemporary classrooms.

In cooperative learning, discussion becomes the indispensable method. Many teachers have realized discussion is a better way than the question-and-answer method. However, a discussion with the whole class is not always the best way 
of getting students talking. Shy and less confident students can hide from the teacher and not necessarily contributive. A useful alternative for promoting productive talk is the use of pairs or small groups (not large than six) combining to talk and work on a specified task.

\section{COOPERATIVE LEARNING IN READING}

Reading is viewed as a process of decoding written symbols, working from smaller unites to larger ones. It is important to bear in mind that reading is not an invariable sill, that there are different types of reading skills that correspond to the many different purposes we have for reading.

In common reading class, the teacher asks the students to read the whole passage, and then answer some questions or do some reading comprehension exercises. Then the teacher explains the important words and phrases. The main task for the students is to read over and over again until they understand the passage thoroughly. In order to raise the efficiency of reading, the teacher can try cooperative learning. We can do as follows:

1) the teacher gives the reading material; 2) the teacher divides the reading material into different parts, each member of the group gets a different part for one material; 3) each member of the group should find the others who get the same part with him and form the 'expert group'; 4) after discussing in the 'expert group', each member should go back to their normal group and exchange opinions about their discussion, then form a complete idea about the material; 5) the teacher asks questions and each member of the group is responsible for the question; 6) the teacher makes a comment about the cooperative reading class.

\section{COOPERATIVE LEARNING IN SPEAKING}

Speaking plays a more and more important role in English learning. Since seldom students can speak fluent English in classroom, it's high time for teachers to apply cooperative learning method in class.

Samples:

A. Students work in pairs. One student has a number of elements (e.g. pictures) arranged in a certain way. The other has the same elements, but loose, and has to arrange them in the same way by talking to his partner without looking at the partner's picture.

B. Students, in pairs, each have similar pictures, but with differences. Through talking to each other, they have to find the differences without looking at each other's picture.

Through cooperative learning method, speaking activities can be highly motivated and students can be willing to open their mouth instead of being afraid of making mistakes in front of the whole class. If teachers have set up the activity properly, and can give useful feedback, students will get tremendous satisfaction from it.

\section{CONCLUSION}

Interaction in small groups, as discussed in the paper, provides a basis for language acquisition. With learners working in groups or pairs they learn how to read and speak effectively, how to work out what texts mean how to gather important information, how to work well in cooperation with others and how to solve language problems in a systematic way. They become skilled at cooperating with others, and express their own opinions, ideas and feelings, guided by the teacher. In a word, cooperative learning method helps students become a real language user in and out of English classroom.

\section{REFERENCES}

[1] Jack C. Richards. \& Charles, Lockhart. (1996). Reflective Teaching in Second Language Classrooms. Cambridge University Press.

[2] Olsen, R. E. W. -B., \& Kagan, S. (1992). About cooperative learning. In C. Kessler (Ed.), Cooperative language learning: A teacher's resource book (pp.1-30). Englewood Cliffs, NJ: Prentice Hall.

[3] Sharan, S. (ed). (1990). Cooperative learning: Theory and Research. New York: Praeger Publisher.

[4] Slavin, R. E. (1990). Cooperative learning: theory, research, and practice. Englewood Cliffs, New Jersey: Prentice Hall.

[5] Swain, M. (1985). Communicative competence: some roles of comprehensible input and comprehensible output in its development in Gass and Madden (eds.). Input in Second Language Acquisition. Rowley, Mass.: Newbury House.

[6] Vermette, P. J. (1998). Making Cooperative Learning Work-Student Teams in K-12 Classroom. Merrill, an Imprint of Prentice hall.

Jing Meng was born in Qingdao, China in 1978. She received her M.A. degree in linguistics from Shandong University, China in 2005 .

She is currently a lecturer at College of Foreign Languages of Qingdao University of Science and Technology, Qingdao, China. Her research interests include language teaching and second language acquisition. 